\title{
EFFECT OF AN INTRAUTERINE DEVICE ON MENSTRUAL CYCLICITY AND LUTEAL FUNCTION IN THE BABOON
}

\author{
W. G. BREED, JUDITH M. STEPHENSON, P. ECKSTEIN, \\ P. V. PEPLOW AND W. R. BUTT* \\ Department of Anatomy, University of Birmingham, and \\ *Department of Clinical Endocrinology, Women's Hospital, Birmingham B11 4HL
}

(Received 20th May 1971, accepted 12th August 1971)

\begin{abstract}
Summary. In the baboon, the presence of an IUD slightly shortens the length of the menstrual cycle and prolongs that of menstruation. Sexual skin changes showed that the part of the cycle shortened was the detumescent ( $=$ secretory) phase, the tumescent $(=$ proliferative) phase remaining unaffected. Plasma progesterone levels during the latter half of the cycle were not affected by the IUD, but the onset of menstruation in experimental animals was associated with a higher blood concentration of progesterone than that present in controls. It is concluded that an IUD does not interfere with luteal function in the baboon.
\end{abstract}

\section{INTRODUCTION}

The mode of action of IUDs remains unknown in both women and other mammals. Most of the present evidence indicates that they act primarily at the uterine level (cf. Eckstein, 1970). Some preliminary findings by Faucher, Ellegood, Mahesh \& Greenblatt (1969) suggest, however, that in women the luteal phase is shorter and urinary pregnanediol excretion is reduced after insertion of an IUD. Marginal shortening of the cycle was also found in rhesus monkeys fitted with IUDs (Eckstein, Kelly \& Marston, 1969), but neither the morphology of the luteal cells nor the responsiveness of the endometrium to decidualizing stimuli appeared to be affected by the presence of a device (Kelly, Marston \& Eckstein, 1969a, b).

In the present study, baboons were used. Unlike the highly tortuous cervical canal of rhesus monkeys, baboons possess a relatively straight one, which greatly facilitates the insertion and removal of IUDs. A second advantage is that their sexual skin undergoes conspicuous periodic changes which are synchronous with the phases of the endometrial cycle, swelling or 'tumescence' of the sexual skin occurring during the proliferative phase and shrinkage ('detumescence') during the progestational part. Since exogenous progesterone has been shown to induce collapse of the sexual skin in baboons (Gillman, 1940), it is assumed that normal detumescence is correlated with, and may be used as a sensitive indicator of, the hormonal activity of the corpus luteum in 
this species. The onset of detumescence does not, however, coincide precisely with, and probably follows a few days after, ovulation (cf. Hendrickx \& Kraemer, 1969; present study).

This paper reports the effects of a plastic IUD on the overall length of the menstrual cycle and that of the tumescent and detumescent stages of the sexual skin cycle, as well as on the plasma concentration of progesterone during the luteal phase.

\section{MATERIALS AND METHODS}

\section{Animals and recording of sexual skin activity}

A total of eight adult, probably parous, baboons, Papio cynocephalus, were used and kept under conditions similar to those described for rhesus monkeys (Eckstein et al., 1969). After an initial quarantine period of about 6 weeks, a daily record of their sexual skin development and menstruation was kept. The degree of sexual skin activity was recorded as follows: $0=$ quiescence; 1 to $2+=$ progressive tumescence; 3 or $3+=$ maximum tumescence; $2+$ to $0=$ progressive detumescence. Thus the first day of detumescence was taken as the day when the sexual skin showed noticeable shrinkage compared with its condition on the previous day. The last day during the detumescent phase before the onset of macroscopical bleeding was taken as the end of the cycle and the first day of menstruation as the beginning of the next cycle.

\section{Collection of blood}

The animals were bled after receiving an intramuscular injection of 0.8 to $1.0 \mathrm{ml}$ phencyclidine hydrochloride (Sernylan, Parke Davis \& Co.; $20 \mathrm{mg} / \mathrm{ml}$ ). This resulted in temporary sedation during which $5 \mathrm{ml}$ blood were withdrawn from a superficial vein. Blood was taken three times a week in this way. The samples were centrifuged immediately at about $3000 \mathrm{rev} / \mathrm{min}$ in heparinized tubes and the resulting plasma pipetted off and stored at $-10^{\circ} \mathrm{G}$ until required for assay.

\section{Insertion and removal of IUDs}

The devices used were shortened Margulies spirals (15 to $20 \mathrm{~mm}$ in diameter and $2 \mathrm{~mm}$ thick). In seven of the eight baboons, insertion of the device into the uterus was performed transcervically during sedation with phencyclidine, using a human IUD inserter. In the remaining female, insertion was by hysterotomy. Subsequent X-ray photography, and in some cases laparotomy, confirmed that all IUDs were correctly placed and had fully re-coiled within the uterine cavity. The IUDs of five of the animals in this study were later removed by means of a Paterson's forceps introduced through the cervix.

\section{Progesterone assay}

Plasma progesterone was determined by the competitive protein-binding method of Johansson (1969), with the following minor modifications. Plasma containing binding protein was obtained from a normal young woman who had taken $50 \mu \mathrm{g}$ ethinyl oestradiol daily for 21 days. The plasma was stored in 
$1-\mathrm{ml}$ aliquots at $-15^{\circ} \mathrm{C}$. The protein-binding solution used in the assay contained $0 \cdot 1 \%$ of this plasma mixed with $\left[1,2-{ }^{3} \mathrm{H}\right]$ corticosterone (Radiochemical Centre, Amersham) with a specific activity of $41.5 \mathrm{Ci} / \mathrm{mmol}$.

Petroleum ether (British Drug Houses; boiling range 30 to $40^{\circ} \mathrm{C}$ ) was washed with sulphuric acid and redistilled twice before use. Estimations on each batch showed extractions of 85 to $90 \%$ of progesterone and of only 10 to $12 \%$ of $17 \alpha$-hydroxyprogesterone. Plasma $(0.5 \mathrm{ml})$ was extracted with $5 \mathrm{ml}$ petroleum ether, and $4 \mathrm{ml}$ of supernatant was withdrawn and evaporated to dryness under nitrogen in a $35^{\circ} \mathrm{C}$ water bath.

Recoveries were $0.99 \mathrm{ng} \pm 0.047$ (S.E.) from an added amount of $1 \mathrm{ng}$ of progesterone, and $1.98 \mathrm{ng} \pm 0.066$ (S.E.) from an added $2 \mathrm{ng}$ of progesterone (sixteen duplicate estimations). The error in repeated determinations was found to be $\pm 0.1 \mathrm{ng}$ (S.E.) for a mean value of $4.81 \mathrm{ng}$ (based on a series of forty-five duplicate estimations) and $\pm 0.03 \mathrm{ng}$ (S.E.) for a mean value of $0.48 \mathrm{ng}$ (thirty-five duplicates).

\section{RESULTS}

Effect of an IUD on the phases of the menstrual cycle and on cycle length

All cycles observed in the eight baboons have been included in the analysis unless they lasted more than 49 days. Cycles exceeding this length were rare (three out of 132, all in animals without IUDs), and may have been due to menstruation being either very brief or microscopic and therefore remaining undetected. If an IUD was inserted or removed during any particular cycle, this was excluded from the analysis. Data on cycle length in animals that had been in the main colony for less than 6 weeks were not included. After this time, no apparent change in the length of the cycle occurred.

Table 1 shows that in each of the eight baboons, the mean cycle length was slightly shorter when the IUD was present. Statistical analysis (paired $t$ test) indicated that the difference between the means, 1.15 days, is significant $(P<0.05)$. This also emerged from an analysis of the pooled data obtained in all eight animals $(P<0.05$; Table 2$)$.

The device had no consistent effect on the tumescent phase of the sexual skin cycle, but the detumescent phase was shortened in seven of the eight females studied (Table 1). An analysis of the group means by paired $t$ test $(P<0.05)$ and of the pooled data from all eight females $(P<0.002$; Table 2$)$ showed that the reduction in the length of the detumescent phase in females fitted with the device was significant.

The length of the cycle in the baboons without IUDs was slightly longer than the mean for 200 cycles considered to be ovulatory in the series of Stevens, Sparks \& Powell (1970), but similar to the means reported by Hendrickx \& Kraemer (1969) and Eckstein \& Zuckerman (1956).

The greater length of the tumescent compared with the detumescent phase of the cycle in females without a device (Tables 1 and 2) is consistent with previous observations in several species of baboon (see Eckstein \& Zuckerman, 1956). It contrasts with the findings of Hendrickx \& Kraemer (1969) who reported no differences in length between the two phases in females isolated from 


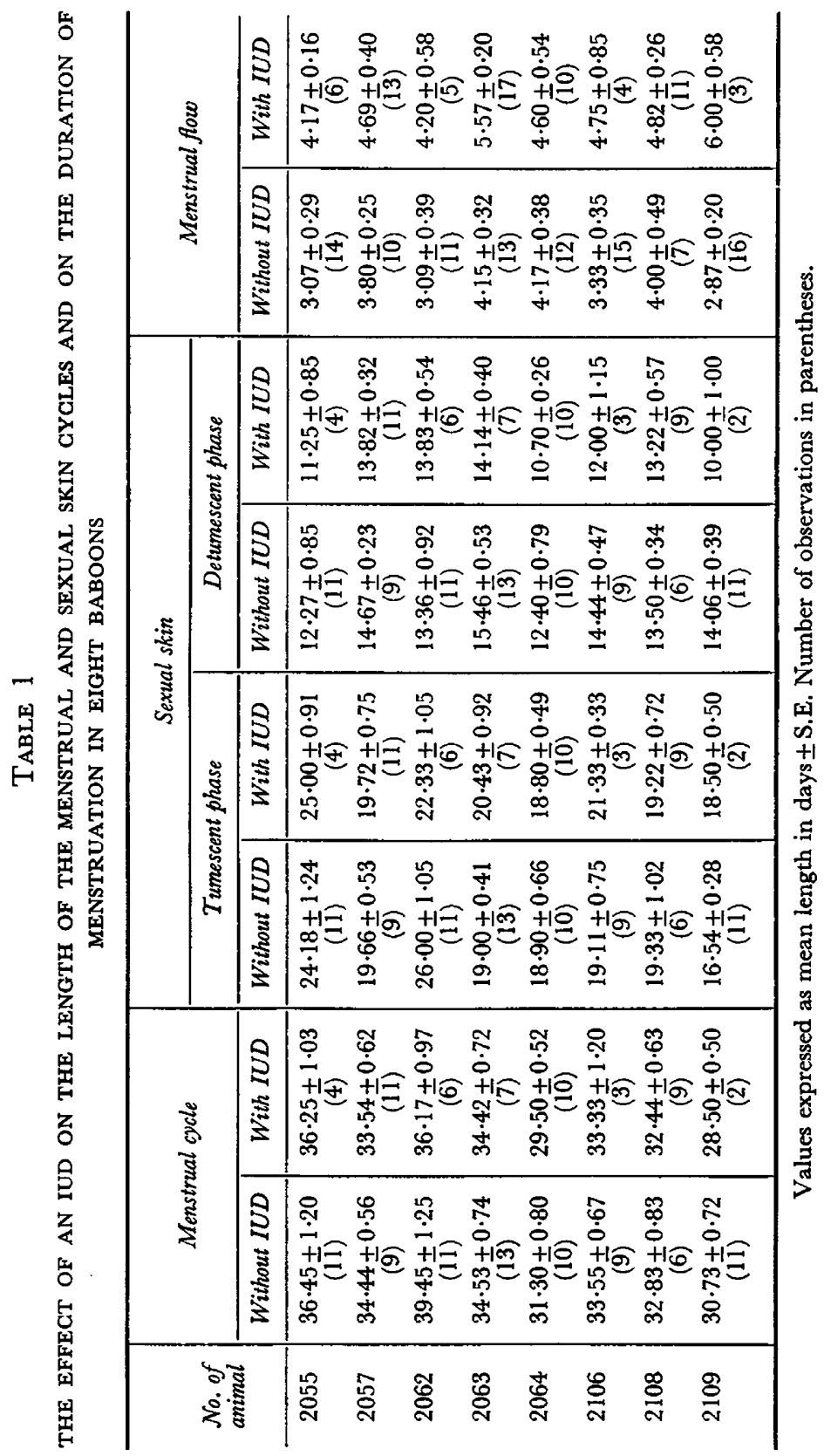


TABLE 2

EFFECT OF AN IUD ON THE MENSTRUAL AND SEXUAL SKIN GYGLE OF EIGHT BABOONS

\begin{tabular}{|c|c|c|c|c|}
\hline & \multicolumn{2}{|c|}{ Days (mean $\pm S . E)}$. & \multirow{2}{*}{$d^{*}$} & \multirow{2}{*}{$\mathbf{P}$} \\
\hline & Without IUD & With IUD & & \\
\hline $\begin{array}{l}\text { Cycle length } \\
\text { Menstrual flow } \\
\text { Tumescent phase } \\
\text { Detumescent phase }\end{array}$ & $\begin{array}{r}34 \cdot 30 \pm 0 \cdot 43(80) \\
3 \cdot 50 \pm 0 \cdot 12(98) \\
20 \cdot 45 \pm 0 \cdot 43(80) \\
13 \cdot 81 \pm 0 \cdot 23(80)\end{array}$ & $\begin{array}{r}33 \cdot 00 \pm 0 \cdot 41(52) \\
4 \cdot 78 \pm 0 \cdot 16(59) \\
20 \cdot 31 \pm 0 \cdot 39(52) \\
12 \cdot 71 \pm 0 \cdot 26(52)\end{array}$ & $\begin{array}{l}2 \cdot 11 \\
6 \cdot 46 \\
0 \cdot 24 \\
3 \cdot 11\end{array}$ & $\begin{array}{c}0.05 \text { to } 0.02 \\
<0.001 \\
>0.05 \\
0.002 \text { to } 0.001\end{array}$ \\
\hline
\end{tabular}

Number of observations in parentheses.

* d value calculated according to Bailey (1959); $\mathrm{n}>30$.

males. Their method of recording sex changes, however, differed somewhat from ours (Hendrickx \& Kraemer 1971).

\section{Effect of an IUD on length of menstruation}

The findings listed in Table 1 also show that, in all eight baboons, the duration of menstruation was prolonged when an IUD was present. The differences between the group means, when analysed by paired $t$ test $(P<0.01)$ and between the pooled data $(P<0.001$; Table 2$)$ are significant. No such difference was found in rhesus monkeys (Eckstein et al., 1969).

\section{Effect of an IUD on plasma progesterone levels}

The results are shown in Table 3 and Text-fig. 1. They are based on observations in only seven baboons owing to the elimination of one female following the spontaneous expulsion of her IUD during the experimental cycle. Each baboon

TABLE 3

PROGESTERONE LEVELS IN PERIPHERAL BLOOD IN SEVEN BABOONS WITH OR WITHOUT IUDS

\begin{tabular}{|c|c|c|c|c|}
\hline \multirow{2}{*}{$\begin{array}{l}\text { Days before } \\
\text { menstruation }\end{array}$} & \multicolumn{2}{|c|}{ Without IUD } & \multicolumn{2}{|c|}{ With IUD } \\
\hline & $\begin{array}{c}\text { No. of samples } \\
\text { assayed }\end{array}$ & $\begin{array}{l}\text { Progesterone } \\
\quad(\text { ng/ml })\end{array}$ & $\begin{array}{c}\text { No. of samples } \\
\text { assayed }\end{array}$ & $\begin{array}{l}\text { Progesterone } \\
\quad(\mathrm{ng} / \mathrm{ml})\end{array}$ \\
\hline $\begin{array}{c}0 \text { and } 1 \\
2 \text { and } 3 \\
4 \text { and } 5 \\
6 \text { and } 7 \\
8 \text { and } 9 \\
10 \text { and } 11 \\
12 \text { and } 13 \\
14 \text { and } 15 \\
16 \text { and } 17 \\
18 \text { and } 19 \\
20 \text { and } 21 \\
22 \text { and } 23 \\
24 \text { and } 25 \\
26 \text { and } 27\end{array}$ & $\begin{array}{l}5 \\
5 \\
7 \\
4 \\
7 \\
7 \\
4 \\
7 \\
7 \\
7 \\
5 \\
5 \\
6 \\
3\end{array}$ & $\begin{array}{l}0.60 \pm 0.06 \\
2.92 \pm 1.01 \\
6.01 \pm 1.00 \\
8 \cdot 19 \pm 0.57 \\
8.56 \pm 1.13 \\
8.17 \pm 1.25 \\
4.56 \pm 0.97 \\
3.83 \pm 0.24 \\
1.69 \pm 0.39 \\
0.81 \pm 0.22 \\
0.35 \pm 0.15 \\
0.47 \pm 0.06 \\
0.54 \pm 0.16 \\
0.43 \pm 0.05\end{array}$ & $\begin{array}{l}6 \\
7 \\
5 \\
7 \\
6 \\
6 \\
4 \\
7 \\
7 \\
5 \\
5 \\
5 \\
5 \\
4\end{array}$ & $\begin{array}{l}1.51 \pm 0.39 \\
4.61 \pm 1.15 \\
7.33 \pm 0.87 \\
8.31 \pm 1.11 \\
9.96 \pm 1.52 \\
7.15 \pm 0.98 \\
4.00 \pm 1.18 \\
3.63 \pm 0.62 \\
1.50 \pm 0.36 \\
0.76 \pm 0.27 \\
0.37 \pm 0.20 \\
0.65 \pm 0.29 \\
0.44 \pm 0.21 \\
0.55 \pm 0.32\end{array}$ \\
\hline
\end{tabular}

Progesterone levels expressed as means \pm S.E. 


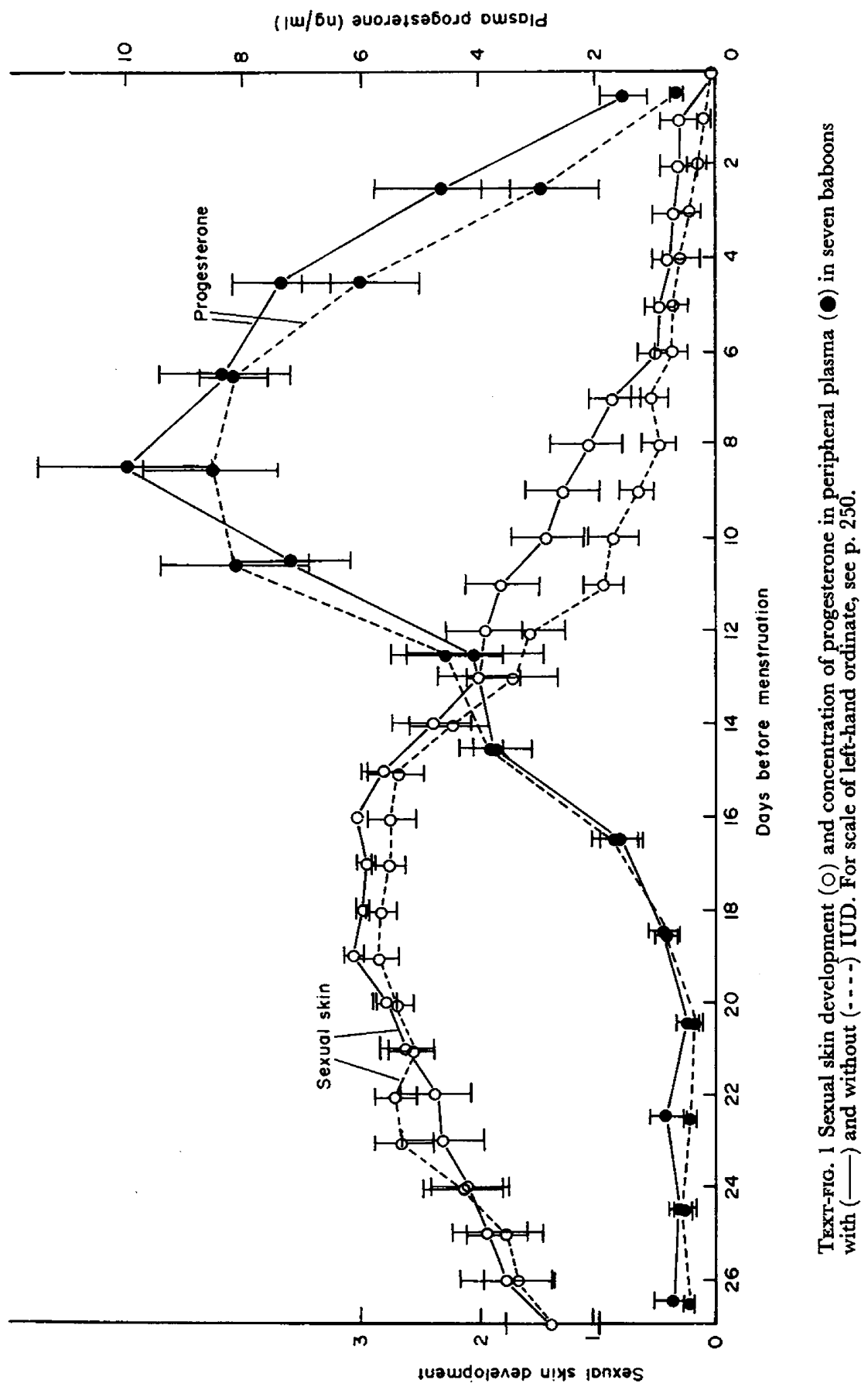


was studied for one complete cycle with the device present and one without it. The cycles ranged from 28 to 36 days. Since luteal development and secretion of progesterone occurs mainly during the second half of the normal cycle, the recorded progesterone levels (in $\mathrm{ng} / \mathrm{ml}$ plasma) have been expressed in terms of days before menstruation (Table 3 ).

It is clear from the Table and Text-fig. 1 that the concentration of progesterone in the peripheral blood during most of the luteal phase was not affected by the presence of a device in the uterus $(P>0.05)$. In both the IUD and non-IUD group of baboons, a marked rise took place about Day 16 before menstruation and continued for about 7 days, after which the concentration declined steadily until menstruation. The onset of bleeding, however, was found to be associated with a higher plasma level of progesterone in the presence of the device (Table 3). Therefore, after completion of the main experiment, three additional samples of blood were obtained at the onset of menstruation and analysed with the eleven results listed in Table 3 . The respective concentrations on Day 0 were $0.52 \pm 0.07 \mathrm{ng} / \mathrm{ml}$ (four samples) without IUD and $1 \cdot 11 \pm 0.29 \mathrm{ng} / \mathrm{ml}$ (four samples) with IUD $(P=0 \cdot 10$ to 0.05 ), and on Day 1, $0.56 \pm 0.11$ (three samples) and $2 \cdot 18 \pm 0.54 \mathrm{ng} / \mathrm{ml}$ (three samples) $(P=0.05$ to 0.02$)$.

\section{Relationship between sexual skin and progesterone levels}

Text-figure 1 shows that the presence of an IUD does not interfere with the full expression of sexual skin activities and that, in animals both with and without the device, the concentration of progesterone starts to rise 2 or 3 days before the sexual skin subsides. Once detumescence has begun, it proceeds rapidly, coincident with a progressive increase in plasma progesterone. In the group of baboons studied, however, the sexual skin showed no sign of renewed activity after the concentration of progesterone had fallen to a barely detectable level; it usually began to swell shortly after the onset of menstruation.

\section{DISGUSSION}

Our study has shown that in the baboon an IUD causes a slight, though significant, reduction in the length of the menstrual cycle, but does not appear to interfere with luteal function, as assessed by the plasma concentration of progesterone.

The reduction in the overall length of the cycle seems to be due to shortening of the detumescent phase of the sexual skin (Tables 1 and 2). Detumescence starts about 2 days after the beginning of the rise in blood progesterone, irrespective of the presence of a device (see Text-fig. 1). These findings, together with the outcome of timed matings just before sexual skin subsidence (Hendrickx \& Kraemer, 1969), suggest that, in normal mature baboons, ovulation precedes the collapse of the sexual skin by about 2 to 3 days. The precise relationship between it and ovulation can, however, only be finally settled by simultaneously determining an ovulatory peak in plasma LH (Stevens et al., 1970) and recovering tubal eggs.

The competitive protein-binding method used in this investigation measures 
primarily plasma progesterone. No chromatographic separation is used, but the major steroids extracted by petroleum ether are progesterone, $20 \alpha$ - and $17 \alpha$-hydroxyprogesterone (Johansson, Neill \& Knobil, 1968). There is no significant competition of $20 \alpha$-hydroxyprogesterone with progesterone for binding sites and only 10 to $12 \%$ of the $17 \alpha$-compound is extracted.

The occurrence of normal blood progesterone concentrations during the luteal phase and the full development of the sexual skin during the proliferative half of the cycle in animals fitted with an IUD indicate that, in baboons, the device does not interfere with the ovarian secretion of either progesterone or oestrogen and exerts no luteolytic effect. This finding differs from the provisional conclusion of Faucher et al. (1969), who reported lower pregnanediol levels in patients following insertion of an IUD. The discrepancy may be due to the small number of women and cycles examined by these authors. Instead, our results support the view of Kelly et al. (1969a, b), based on histological observations on the corpora lutea and endometrium, that luteal function in rhesus monkeys is unaffected by the presence of an IUD. In species such as the ewe (Nalbandov, Moore \& Norton, 1955; Ginther, Pope \& Casida, 1966; Bhalla \& Casida, 1970), cow (Ginther, Wood, Janakiraman \& Casida, 1966) and guinea-pig (Bland \& Donovan, 1966; Ginther, Mahajan \& Casida, 1966), intrauterine foreign bodies exert a marked luteolytic effect. In these and some other species, however, hysterectomy prolongs the functional life of the corpora lutea, thus implying the existence of a uterine luteolytic factor upon which an IUD might act. By contrast, hysterectomy does not appear to extend the lifespan and hormonal function of the corpus luteum in primates (e.g. Neill, Johansson \& Knobil, 1969; Doyle, Barclay, Duncan \& Kirton, 1971).

An interesting additional finding in the present study is the fact that, in the baboons with IUDs, menstruation started with higher blood levels of progesterone than in females without the devices. This could account for the shorter length of the menstrual cycle and of the detumescent phase in the animals with IUDs. It is possible that an IUD may alter the sensitivity of the endometrium to endogenous progesterone; such a conclusion has already been drawn from studies in rats (Psychoyos, 1966; Chaudhury \& Sethi, 1970) and mice (Martin \& Finn, 1970).

The contraceptive action of IUDs in sub-human primates has so far only been established in rhesus monkeys (Kelly et al., 1969a). While this remains to be confirmed for the baboon, it can be concluded that the devices do not alter ovarian function in this species, but may affect uterine responsiveness to progesterone.

\section{ACKNOWLEDGMENTS}

We wish to thank Mrs A. Fraser and Mr R. Morris for skilled technical assistance, and Mr A. Smith, Mr F. James and Mr G. Tonks for care of the animals. The financial support of the Ford Foundation is gratefully acknowledged.

\section{REFERENCES}

BaILey, N. T. J. (1959) Statistical methods in biology. English Universities Press, London. 
Bhalla, R. G. \& Casida, L. E. (1970) Luteolytic action of intrauterine devices in sheep as affected by duration of progesterone influence and by the age of the corpus luteum. Biol. Reprod. 3, 214.

Bland, K. P. \& Donovan, B. T. (1966) The uterus and control of ovarian function. Adv. reprod. Physiol. 1,179 .

Ghaudhury, R. R. \& Sethi, A. (1970) Effects of an intra-uterine contraceptive device on mitosis in the rat uterus on different days of pregnancy. 7. Reprod. Fert. 22, 33.

Doyle, L. L., Barclay, D. L., Duncan, G. W. \& Kirton, K. T. (1971) Human luteal function following hysterectomy as assessed by plasma progestin. Am. J. Obstet. Gynec. 110, 92.

Eckstein, P. (1970) Mechanism of action of intrauterine contraceptive devices in women and other mammals. Br. med. Bull. 26, 52.

Eckstein, P., Kelly, W. A. \& Marston, J. H. (1969) Effect of an intra-uterine device on menstrual periodicity in the rhesus monkey. F. Reprod. Fert. 19, 133.

Eckstein, P. \& Zuckerman, S. (1956) The oestrous cycle in the Mammalia. In: Marshall's Physiology of Reproduction, 3rd edn, Vol. I/1, Chap. 4. Ed. A. S. Parkes. Longmans, Green, London.

Faucher, G. L., Ellegood, T. O., Mahesh, V. B. \& Greenblatt, R. P. (1969) Urinary estrogens and pregnanediol before and after insertion of an IUCD. Am. 7. Obstet. Gynec. 104, 502.

Gillman, J. (1940) The effect of multiple injections of progesterone on the turgescent perineum of the baboon (Papio porcarius). Endocrinology, 26, 1072.

Ginther, O. J., Pope, A. L. \& Casida, L. E. (1966) Local effect of an intrauterine plastic coil on the corpus luteum of the ewe. F. Anim. Sci. 25, 472.

Ginther, O. J., Mahajan, S. \& Casida, L. E. (1966) Local ovarian effects of an intrauterine device in intact and unilaterally ovariectomized guinea pigs. Proc. Soc. exp. Biol. Med. 123, 775.

Ginther, O. J., Wood, C. O., Janakiraman, K. \& Casida, L. E. (1966) Effect of an intra-uterine plastic coil on the oestrous cycle of the heifer. 7. Reprod. Fert. 12, 193.

Hendrickx, A. G. \& Kraemer, D. C. (1969) Observations on the menstrual cycle, optimal mating time and pre-implantation embryos of the baboon, Papio anubis and Papio cynocephalus. F. Reprod. Fert. Suppl. 6, 119.

Hendrickx, A. G. \& Kraemer, D. C. (1971) Reproduction. In: Embryology of the Baboon, Chap. 1, p. 3. Ed. A. G. Hendrickx. University of Chicago Press, Chicago and London.

Johansson, E. D. B. (1969) Progesterone levels in peripheral plasma during the luteal phase of the normal human menstrual cycle measured by a rapid competitive protein-binding technique. Acta endocr., Copenh. 61, 592.

Johansson, E. D. B., Neill, J. D. \& Knobil, E. (1968) Periovulatory progesterone concentration in the peripheral plasma of the rhesus monkey with a methodologic note on the detection of ovulation. Endocrinology, 82, 143.

Kelly, W. A., Marston, J. H. \& Eckstein, P. (1969a) Effect of an intra-uterine device on conception and ovulation in the rhesus monkey. 7. Reprod. Fert. 19, 143.

Kelly, W. A., Marston, J. H. \& Eckstein, P. (1969b) Effect of an intra-uterine device on endometrial morphology and the deciduomal reaction in the rhesus monkey. 7 . Reprod. Fert. 19, 331.

Martin, L. \& Finn, C. A. (1970) The effects of an intra-uterine device on uterine cell division and epithelial morphology during early pregnancy in the mouse. 7 . Endocr. 48, 347.

Nalbandov, A. V., Moore, W. W. \& Norton, H. W. (1955) Further studies on the neurogenic control of the estrous cycle by uterine distention. Endocrinology, 56, 225.

Neill, J. D., Johansson, E. D. B. \& Knobil, E. (1969) Failure of hysterectomy to influence the normal pattern of cyclic progesterone secretion in the rhesus monkey. Endocrinology, 84, 464.

Psychoyos, A. (1966) Recent researches on egg implantation. In: Egg Implantation, p. 4. Eds. G. E. W. Wolstenholme and M. O'Connor. Giba Foundation Study Group No. 23. Churchill, London.

Stevens, V. G., Sparks, S. J. \& Powell, J. E. (1970) Levels of estrogens, progestogens and luteinizing hormone during the menstrual cycle of the baboon. Endocrinology, 87, 658 . 